\title{
The Quality of Arabic Language Teachers in Malaysia: Facing the Fundamental Issues
}

\author{
Zamri Ariffin \\ M. al-Muslim \\ Faculty of Islamic Studies, National University of Malaysia, Malaysia \\ Email: almuslim@ukm.edu.my
}

\section{Doi:10.5901/mjss.2015.v6n1p544}

\section{Abstract}

The effectiveness of teaching and learning that is always reflected through the results obtained by the students actually depends on the quality the teachers. Therefore, many teacher standards have been devised, such as the NBPTS in the United States and the Malaysian Teacher Standards by the Malaysian Ministry of Education. However, there is still the question of their suitability to be used to determine and measure the quality of the Arabic teachers due to the ambiguity of definition and elements used therein. Apart from that, the existence of the one-fit-all quality measurement is also questioned. This paper presents the synthesis study that looks into the methods of how teacher effectiveness in general is measured in the recent teacher assessment studies. The importance of local elements in the quality study is also discussed. This study also takes into consideration the recommendations made by previous studies in the determination of the definition of the student achievement construct as a tool to evaluate the effectiveness and quality of teachers. The Malaysian Teacher Standards are also discussed appropriate to its status within the Malaysian education system. All of the findings are synthesised by the development of a new and comprehensive assessment framework for the quality evaluation of the Arabic teachers from the perspective of Arabic language education in Malaysia. From the synthesis study, the writer would like to propose a logical and practical framework in the teacher assessment field especially for the Arabic Language teachers in Malaysia.

Keywords: assessment, teacher quality, arabic language teachers

\section{Introduction}

Teacher is no doubt a noble profession. For Muslims, this profession is even an inheritance to the duties of the Prophets. Therefore, teachers are held in high esteems in the eyes of the society. Over time, the teacher profession evolves into a more challenging job. Teachers are faced with a variety of demands fitting the current needs and development. They are not only responsible for their students, but also plays a dominant role in realizing the inspirations of their religion, people and the nation that are also a part of the National Education Philosophy. In the context of student learning, quality teachers are an essential factor. Even though other factors such as family background, demography, economical status and social status can also influence the achievement of a student, the quality of the teachers remains a more dominant and significant factor. Therefore, the return on investments into improving of the quality of teachers is more significant than the investments made to improve the educational system by the increasing the teachers' salary, reducing the class size by means of increasing the numbers of new classes and other expenses related to education (Andrews, 2012; Croninger, Rice, Rathbun, \& Nishio, 2007; Goe, 2007; Lovat \& Toomey, 2009). If a transform in the Arabic language education were to be done in Malaysia, the main focus would have to be the training and providing quality teachers that are able to face the current educational challenges. The priorities in this transformation policy will have to be arranged according to the consensus of the scholars that the quality of the teachers is the most important factor in the success of the students.

There would be no good education without good teacher quality (Lin, Xie, Jeng, \& Huang, 2010)

In Malaysia, the desire to increase the numbers of efficient and quality teachers has been translated into a variety of programs. It starts with the selection of teacher candidates, training, induction, continuous professional development until the assessment stage and the teachers' own performance management. In December 2011, the Malaysian Teacher Standard (SGM) Document was launched as a reference and guide to empower and sustain quality teachers. SGM outlines the competency criteria for professional teachers or the standards that must be fulfilled and the necessities that 
must be provided by the agencies and teacher training institutes in order to assist them to achieve the required competency level (Economic Planning Unit, 2010).

Despite the aspirations of the authorities, Arabic teachers for instance, hold a huge responsibility in the field of their own in tandem with the current challenges of Arabic language education. Their biggest challenge will be to restore the pride of the Arabic language education in the national education system as well as within the culture of the majority of the society in Malaysia. This is because the Arabic language education has been rated as unsuccessful (Ishak Rejab, 1992). The issue of the special status of the Arabic language in the national education system and the recent situation revolving around the Arabic language education only adds to the responsibilities of the Arabic teachers. To be able to move forward and bear this huge responsibility largely depends on the quality and competency of the existing Arabic teachers. However, the main question behind the pressing matter is; are the Arabic teachers provided truly fulfil the criteria of a language educator? (Azman Che Mat \& Goh Ying Soon, 2010).

Despite that requiring an urgent answer in order to fulfil the requirements set by the authorities and to alleviate the stress on the Arabic education system, there are still several basic questions regarding the criteria that need to be solved first. If this preliminary step is not done first, surely more answers will rise for the above question due to the disagreements on how the foundation was built. What is meant here by the 'preliminary step' is to answer the question 'who is a quality Arabic teacher'.

\section{Literature Review: Quality Teacher Concept}

The importance of teachers in the success of education has been agreed upon long ago. The quality of the teachers has also been identified as the leading factor above any other aspects especially in the context of teaching and learning in schools (School-Based Factor). Therefore, the concept and understanding of quality teachers have already been discussed since 1970s and still today (Blanton, Sindelar, \& Correa, 2006). Even so, the definitions and the teacher quality assessment methods are still unclear and debated until now. Howevere, the ambiguity of the definition of quality teachers does not mean that there are no specific indicators used as a proxy to a quality teacher. There are also many quality assessment studies done based on certain criteria (Goe \& Stickler, 2008). However, the term 'quality teacher' is still considered unclear due to the absence of an agreement from the scholars on the definition and the dimensions that represent the quality teacher concept (Blanton et al., 2006; Burnett \& Meacham, 2002; Fuller, Young, \& Baker, 2010; Goe, 2007). According to Cavaluzzo (2004), there have been no agreements on the actions that contribute to quality teaching.

\subsection{Good Teacher vs. Effective Teacher}

The difference in the evaluation and assessment of teachers happens for several reasons. One of the reasons is the difference in understanding of the quality teacher concept between a good teacher and an effective teacher. Fenstermacher \& Richardson (2005) first revealed the meaning behind the teacher quality themes between Good Teaching and Effective Teaching. The teacher quality if defined by good teaching only focuses on the process (and input). On the other hand, effective teaching takes into consideration the changes that occurs in the target group especially students.

What happens in the teacher assessment world right now originates from the good teacher or effective teacher criteria. Assessment studies done based on good teacher criteria focuses on the individual itself. A good teacher is seen from his/her knowledge, teacher training undergone, certificates received, attitude, teaching methods and other aspects related to the individual. In simple words a highly qualified Arabic teacher is a teacher equipped with good teaching skills. Several countries around the world apply the good teacher concept as the teacher standard in their educational system. It includes the Malaysian Teacher Standard (SGM) introduced by the Ministry of Education that also applies to Arabic teachers. True to its concept, SGM give special attention to three standards;

1. Professional Teaching Practice Values Standard

2. Knowledge and Understanding Standard

3. Teaching and Learning Skills Standard

At the same time, there is also an inclination towards the effective teacher concept in teacher assessment. The educational goal is to see a change inside the students as the outcome of the teaching process. In this context, a high quality Arabic teacher will be a teacher who demonstrates the capabilities of being able to increase the students' level of knowledge and skills throughout the Arabic language learning process. In Western countries such as the United States, teacher assessment based on added values is often used in secondary levels. The value-added model is manifested 
from the belief that the success of students is the reflection of a quality teacher. This model is specifically designed to determine the contribution or impact of a certain teacher towards the score that the students received over a specified period of time. Based on this objective, it has been used in teacher assessment studies to identify the contributions of a teacher towards the achievement of students. Education authorities are seen more inclined towards this method of assessment. Besides the availability of student achievement data for the assessment, the results from the study that is more consistent and straightforward becomes a reason for the education researchers and the authorities to have a tendency to use this method (Blanton et al., 2006). Despite this idealistic concept, there are doubts that rise due to the suitability and practicality of this value-added model. According to Goe (2007) there are three issues that ruin the quality teacher dimensions if only assessed through the achievement of students.

1. Uniform achievement examinations are designed to evaluate the achievements of students. Students' tests are not tailored to assess the quality of the teachers.

2. There present some difficulties in determining which specific achievement or how far the achievement can be attributed to the teacher or class factor.

3. Impossibility to obtain the data that relates a certain student with a certain teacher at a given time.

In the context of Arabic language education in Malaysia, it was found out that there almost never was any implementation of the student improvement concept as the teacher quality indicator. The same happens with the other subjects as well. The Malaysian Teacher Standard framework and the selection of Excellent Teachers based on subjects by the Ministry of Education's inspectorate have always considered the good teacher concept and not the effective teacher concept. This is clearly seen in the set of criteria determined in the SGM and Excellent Teacher documents (refer to the appendices).

\subsection{Quality Assessment in Islam}

The teacher profession is both a worldly and a purely religious practice. Arabic study is especially more of it since it is the formal language for Islam. In Malaysia, Arabic is taught because it is encouraged by the religion (Nik Mohd Rahimi, Kamarulzaman Ab. Ghani, \& Mowaffak Abdullah, 2008). Therefore, quality in the profession is of a demand. The concept of quality in any kind of occupation or practice is mentioned in several sayings of the Prophet PBUH in the terms used such as al-itqan and al-ihsan (Ibn Sad 1968; al-Bayhaqi 2003; Ibn Adi 1984; Abu Nuaim 1998).

The Quran has also laid down the main reason why a Muslim must perform his responsibilities with the utmost of quality in Surah al-Taubah, verse 105;

And say: "Work (righteousness): Soon will Allah observe your work, and His Messenger, and the Believers: Soon will ye be brought back to the knower of what is hidden and what is open: then will He show you the truth of all that ye did."

In understanding this verse, Muhammad Rashid Rida (1990) stressed that a Muslim who believes that Allah SWT sees all his actions should perfect all his deeds. Allah's attributes of the All Seeing and All Knowing demands for a Muslim to perform his best regardless if it is for himself or for his ummah. A good deed if perfected will not just elevate the individual's own status in the sight of Allah but also in amongst the people (Muhammad al-Khatib, 1964).

The Prophet PBUH also mentioned the importance of quality in performing a task. He demonstrated its importance even though it is only on the exterior. During the burial of his son Ibrahim, the Prophet PBUH saw some gaps in between the stone blocks and he commanded that they were to be properly arranged. Afterwards the Prophet PBUH said:

Indeed it (the gap) does not bring any benefit or harm (to the deceased) but (closing it) will bring comfort to the eyes of the living. Indeed Allah loves a person amongst you who, if he does something, he perfected it (Ibn Sad 1968; Abu Nuaim 1998)

The quality concept in Islam has been discussed by Al-Munawi (1994) in which he stressed several important factors so that a profession can achieve the standard of quality desired by Allah SWT. Any individual given a responsibility has to complete it with all the knowledge that he possesses. The main objective of a task is to make sure that it contributes to the benefit of all creatures. Al-Munawi (1994) also asserts that a task has to be done based on the demands of a quality work and not because of the rate of pay or to just simply discharge the responsibilities. This Islamic concept if applied into the Arabic education profession, a quality Arabic teacher will be one who (1) uses all of his/her expertise in the subject and pedagogy in the teaching and learning, and (2) successfully develops his/her students. These qualities shall remain with them as teachers throughout their lives regardless of their pay grade and rank. 


\section{Proposed Malaysian Arabic Teacher Quality Assessment Framework}

After giving an overview of the quality concept that is based on multiple forms of measurements and assessments for quality teachers around the world including Malaysia, the writer would like to suggest several improvements and changes in the practice especially for implementation in Malaysia. The transform in the Arabic language education will depend on what needs to be improved. Mostly, what needs to be transformed is the assessment method. Assessments are done in order to gain certain important information. That makes the assessment method very significant in achieving the objectives of education. The proposed Arabic teacher quality assessment framework will cover various aspects including;

\subsection{Quality Assessment Dimension}

Hanna \& Gimbert (2011) proposed that education researchers should build a comprehensive and holistic teacher quality model. Recently, there has been an inclination towards considering the multiple dimensions contained within the concept and definition of a quality teacher and associating it with one another. Fenstermacher \& Richardson (2005) for instance, considered two dimensions in parallel as follows: (1) Good teaching; this dimension involves the expectations towards the teacher profession that needs to be fulfilled such as having a certificate, sufficient knowledge in the area and such, and (2) Effective teaching; this means that the teachers' interventions in teaching and learning also need to be considered. Speaking at the same wavelength, Blanton et al. is of the opinion that traditional researches that depend on certain understanding towards the teacher quality concept needs to be grouped into several forms of evaluation. For example, the teacher education practice needs to be associated with teacher quality and the teacher quality with students' achievements. Associating teacher quality with the students' achievements especially will draw acceptance from many parties including the policy makers. Several other researchers also voiced out the same recommendations. They emphasised the importance and the need to conduct researches that considers all the indicators and variables related to teacher quality (Wayne \& Youngs, 2003; Wichadee, 2010).

This recommendation is only logical and practical since there are many variables that represent a quality teacher that are interrelated. For example, the level of teacher education is usually correlated with age, experience and academic capacity. On the other hand, certification is often correlated with the knowledge on the subject, education training and experience (Darling-Hammond \& Youngs, 2002). Goe (2007) also agrees to the association of these dimension based on his research that presents the advantages and disadvantages of all the mechanisms for determination and assessment of teacher quality. Seeing the teacher quality concept from multiple dimensions will reduce the assessment deficiencies and defects when only one dimension is considered.

Therefore, after considering the recommendations by the scholars as mentioned above, the writer proposes a dimension for the assessment of Arabic teachers in Malaysia which involves several dimensions concurrently. The dimensions are the teacher qualification dimension, teacher character dimension, teaching practices dimension and student output dimension. The assessment of Arabic teacher quality must involve all these dimensions altogether.

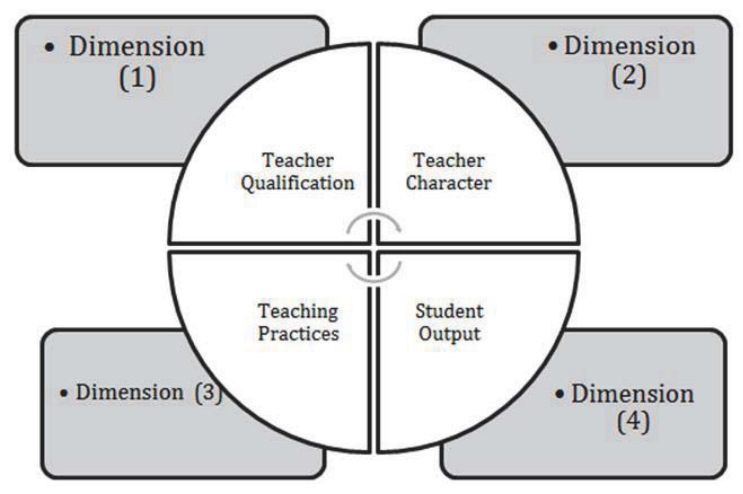

Diagram 1.0 Four (4) Dimensions of Arabic Teacher Assessment General Framework

With the association of the four (4) dimensions, Arabic teacher quality assessment will have used both of the good teacher and effective teacher concepts. The use of the student output dimension is simplified by the existence of data from the centralised and periodic examinations organised by the ministry every year. 


\subsection{Adoption of Local Elements}

Evaluations and assessments performed often include the whole system without considering the differences and diversities contained within. SGM for instance, is used on all teachers at all the different levels of education as well as for all subjects. This happens with the Ministry of Education's Excellent Teacher criteria as well. From a point of view, it can be seen as a uniform and simple system that gives a fair assessment to everyone. However, from another point of view, a bulk evaluation such as this does not help much in identifying the weaknesses and improvement measures that should be taken. Different subjects as well as different levels of education have different objectives and their own approach that shapes the direction of an education. So it is natural that a subject differs from another. In the ministry, the Pendidikan Islam subject is placed together with the Arabic subject in terms of personnel, administration and even assessments when in fact both of these subjects are actually different in many aspects. Pendidikan Islam is more of educating morals and cultivating virtues. Arabic on the other hand is more of developing language skills. Therefore, the nature of a murabbi as an exemplary role model for the students is required for a Pendidikan Islam teacher and is assessed as such. However, the same criteria should not be applied to Arabic teachers, or at least not at the same level of expectations.

In order to determine the items that are suitable with the Arabic teaching and learning criteria so that all dimensions could be represented in the assessment, an independent and systematic field study needs to be conducted. Interest groups related to Arabic teachers such as headmasters, colleagues, policy makers, teacher education institutes such as universities and IPG as well as the students would be the targets for this study. Their understanding of all the dimensions could also be studied at the same time. Observational studies on these target groups makes it possible for the local elements to be considered for the evaluation and assessments of Malaysian Arabic teachers. What does the Arabic teachers need to master? How or what are the educational practices that could cultivate Arabic language skills? Do the Arabic teachers actually help the students to master the language? These specific questions can never be answered based on theories alone, but requires a reality check through regular and consistent studies. A study in Israel on the criteria of foreign teachers (including Arabic teachers) over there found out that the knowledge of the language culture is not important neither helpful in a language study (Brosh, 1996). This idea is completely against the general theory that understanding the culture is fundamental in learning a language. Is it the same with the Arabic language education in Malaysia that is ranked between the second language and foreign language? This is where the need for the understanding of the local situation that is represented by the individuals directly involved in the Arabic language education comes in. Here is an example from the student dimension. Does the exam results actually reflect language skills? Can other aspects such as students' increasing confidence, interest and expectations towards the subject also be a part of the output of an efficient learning? The response towards these questions requires an explorational study into the local elements and is important since it considers the local situation of Arabic language education in line with the concept of quality itself that differs from place to place (Burnett \& Meacham, 2002).

\subsection{The Role of Students as The Education Target}

Burnett \& Meacham (2002) suggested that the understanding of teacher quality from the perspective of students to be considered apart from the focus on what the students achieve, what the teachers do or the teachers' qualifications. This idea needs to be examined because most teacher assessment studies are done based on ancillary data gained from incidental samples and not from direct observations or the perceptions of the students as the primary education target. Students are the group that will be directly affected by the teachers compared to the other groups of respondents. Furthermore, the data obtained from teacher observations or self-assessment has low credibility compared to the data from the students (Anon 2010). However, Wichadee (2010) recommends that both data are gathered and compared in order to maintain balance when selection is made. As for the teachers, it is also beneficial to know what are the characteristics that the students consider high quality teachers should have.

The role of students in the assessment of teachers needs to be expanded to include all the aspects that are considered as positive changes in the Arabic language education. Evaluating Arabic teachers should not only focus on observing the improvements in the examination results alone, but rather to include the changes in the mental and spiritual attitudes towards the Arabic language such as interest, desire to know more, efforts outside the scope of the syllabus and others. This also requires for local studies to be done into students' and related parties' expectations from the learning process with the teachers in the context of Arabic language education in Malaysia. 


\section{Conclusion}

The objectives, approach, method and the selection of analysis units for a study depend on the foundational framework. The way the mold is built will determine the outcome of the study. Before Arabic teachers are assessed, the questions regarding the assessment parameters should be solved first and must be accepted by all. In this paper, the writer has offered his opinion together with recommendations on how to realize it. All the goods offered are all from Allah and all the shortcomings come from the weakness of the writer himself. The writer's biggest hope is to elevate the status of the Arabic language in the Malaysian education system. This is where the love was born.

\section{References}

Abu Nuaim. (1998). Marifat al-Sahabah. Riyadh: Dar al-Watan Li al-Nashr.

Al-Bayhaqi. (2003). Shuab al-Iman. Riyadh: Maktabat al-Rushd Li al-Nashr Wa al-Tawzi.

Al-Munawi. (1994). fayd al-Qadir Sharh al-Jami al-Saghir Min Ahadith al-Bashir al-Nadhir. Beirut: Dar al-Kutub al-Ilmiyyah.

Andrews, S. L. (2012). Impact of Teacher Qualification on Student Achievement at the Elementary and Middle School Levels. Walden University.

Azman Che Mat, \& Goh Ying Soon. (2010). Cabaran -cabaran Dalam Pengajaran Bahasa Arab sebagai bahasa asing pilihan di IPT: Kajian kes. AJTLHE: ASEAN Journal of Teaching and Learning in Higher Education, 2(2), 9-21.

Blanton, L. P., Sindelar, P. T., \& Correa, V. I. (2006). Models and Measures of Beginning Teacher Quality. The Journal of Special Education, 40(2), 115-127. doi:10.1177/00224669060400020201

Brosh, H. (1996). Perceived Characteristics of the Effective Language Teacher. Foreign Language Annals, 29(2), 125-136. doi:10.1111/j.1944-9720.1996.tb02322.x

Burnett, P. C., \& Meacham, D. (2002). Measuring the Quality of Teaching in Elementary School Classrooms. Asia-Pacific Journal of Teacher Education, 30(2), 141-153. doi:10.1080/13598660220135658

Cavalluzzo, L. (2004). Is National Board Certification an effective signal of teacher quality? Virginia: The CNA Corporation. Retrieved from http://www.nbpts.org/UserFiles/File/Final_Study_11204_D_-_Cavalluzzo_-_CNA_Corp..pdf

Croninger, R. G., Rice, J. K., Rathbun, A., \& Nishio, M. (2007). Teacher qualifications and early learning: Effects of certification, degree, and experience on first-grade student achievement. Economics of Education Review, 26(3), 312-324. doi:10.1016/j.econedurev. 2005.05 .008

Darling-Hammond, L., \& Youngs, P. (2002). Defining "Highly Qualified Teachers": What Does "Scientifically-Based Research" Actually Tell Us? Educational Researcher, 31(9), 13-25. doi:10.3102/0013189X031009013

Fenstermacher, G. D., \& Richardson, V. (2005). On Making Determinations of Quality in Teaching. Teachers College Record, 107(1), 186-213. doi:10.1111/j.1467-9620.2005.00462.x

Fuller, E., Young, M., \& Baker, B. D. (2010). Do Principal Preparation Programs Influence Student Achievement Through the Building of Teacher-Team Qualifications by the Principal? An Exploratory Analysis. Educational Administration Quarterly, 47(1), 173-216. doi:10.1177/0011000010378613

Goe, L. (2007). The link between teacher quality and student outcomes: A research synthesis (pp. 1-72). Washington DC: National Comprehensive Center for Teacher Quality. Retrieved from http://secc.sedl.org/orc/resources/LinkBetweenTQandStudent Outcomes.pdf

Goe, L., \& Stickler, L. M. (2008). Teacher Quality and Student Achievemant: Making The Most of Recent Research. TQ Research \& Policy Brief. National Comprehensive Center for Teacher Quality.

Ibn Adi. (1984). al-Kamil Fi Duafa' al-Rijal. Beirut: Lubnan al-Makatib.

Ibn Sad. (1968). at-Tabaqat al-Kubra. Beirut: Dar Șadir.

Ishak Rejab. (1992). Masalah Pengajaran dan Pembelajaran Bahasa Arab di Malaysia. In Ismail Ab. Rahman (Ed.), Pendidikan Islam Di Malaysia. Bangi: Penerbit UKM.

Lin, R., Xie, J., Jeng, Y.-C., \& Huang, S. (2010). The Relationship between Teacher Quality and Teaching Effectiveness Perceived by Students from Industrial Vocational High Schools. Asian Journal of Arts and Sciences, 1(2), 167-187. Retrieved from http://203.72.2.115/Ejournal/AM01010202.pdf

Lovat, T., \& Toomey, R. (2009). Values education and quality teaching. Values Education and Quality Teaching. Springer. Retrieved from http://www.springerlink.com/index/N258J34R4171V573.pdf

Muhammad al-Khatib. (1964). Awdah al-Tafasir. Kaherah: al-Matbaah al-Misriyyah Wa Maktabatuha.

Muhammad Rashid Rida. (1990). Tafsir al-Manar. Kaherah: al-Hayah al-Misriyyah al-Amah.

Nik Mohd Rahimi, Kamarulzaman Ab. Ghani, \& Mowaffak Abdullah. (2008). Fann Tadris al-Lughah al-Arabiyyah Li Ghayr al-Arab. Bangi: Fakulti Pendidikan, UKM.

Unit Perancang Ekonomi. (2010). Rancangan Malaysia Kesepuluh 2011-2015. Putrajaya.

Wayne, A. J., \& Youngs, P. (2003). Teacher Characteristics and Student Achievement Gains: A Review. Review of Educational Research, 73(1), 89-122. doi:10.3102/00346543073001089

Wichadee, S. (2010). Characteristics of Effective English Language Teachers: The Perspectives of Bangkok University Students. BU Academic Review, (Jan-June). Retrieved from http://www.bu.ac.th/knowledgecenter/epaper/jan_june2010/pdf/Page_01.pdf 


\section{Appendix A}

\section{Malaysian Teacher Standard}

The Teacher Education Division (BPG) of the Ministry of Education Malaysia has taken the initiative to draft the teacher standard as a reference point and guide for teachers, teacher educators, agencies and teacher education institutes in Malaysia. The standard covers the three aspects below:

\section{Standard 1: Professional Teaching Practice Values Standard}

This standard discusses the competence of professional teaching practice values based on self, profession and social domains that a teacher should have. Professional Teaching Practive Values is developed based on the culture of the Institute for Teacher Education (IPG), Teaching Profession Conduct, noble values in the school curriculum, the key values in public service, the main principle of the MOE Work Ethics, and the Twelve Pillars.

\section{Standard 2: Knowledge and Understanding Standard}

This standard discusses the competence of knowledge and understanding of the specialised subject, educational sciences, curriculum and co-curriculum that a teacher should have. A teacher that owns and masters the knowledge will be able to elevate the teacher professionalism, perform their duties efficiently and effectively as well as be more creative and innovative.

\section{Standard 3: Teaching and Learning Skills Standard}

This standard discusses the competence of teaching and learning capabilities that teachers should master. This standard focusses on the ability of the teacher to plan, execute and assess the academic and co-curriculum teaching and learning.

\section{Appendix B}

Excellent Teachers have the following excellent qualities:

Personal: An Excellent Teacher is a teacher with a noble character, competent and stands firm on the teacher and public service ethics as well as being aware and concerned of the needs of his/her students and able to become a role model for the other educators.

Knowledge and skills: An Excellent Teacher is able to master and appreciate the contents of the subject or his/her specialised area and expertise, able to become a teaching and learning consultant, intelligently manages time, resources, teaching and learning tools, able to recognize the students' education needs and problems thus prepare a follow-up program, skilled and knowledgable in information and communications technology.

Job outcomes: An Excellent Teacher is a teacher who is able to improve the learning outcomes towards developing the students' potential in line with the National Education Philosophy.

Potential: An Excellent Teacher is a teacher with a vision, is proactive, takes initiative, and is responsive and innovative in carrying out their duties as educators.

Contribution to the advancement of education: An Excellent Teacher is a teacher who is able to generate new ideas in the subject or area of specialization, and share ideas for the improvement of the quality of education. 